Jurnal Teknik Komputer AMIK BSI

Volume VI No.1 Januari 2020

P-ISSN 2442-2436, E-ISSN: 2550-0120

Akreditasi Ristekdikti, No: 21/E/KPT/2018

DOI: $10.31294 /$ jtk.v4i2

\title{
Model Waterfall Untuk Pengembangan Sistem Informasi Pengolahan Nilai Pada SMP Kartika XI-3 Jakarta Timur
}

\author{
Amrin $^{1}$, Mita Diah Larasati², Irawan Satriadi ${ }^{3}$ \\ ${ }^{1,2,3}$ Teknologi Informasi, Universitas Bina Sarana Informatika \\ e-mail: amrin.ain@bsi.ac.id \\ Irawan.irs@bsi.ac.id

Diterima Direvisi Disetujui \\ 15-11-2019 03-01-2020 02-02-2020
}

\begin{abstract}
Abstrak - Sistem informasi berbasis web pada saat ini sudah menjadi sarana yang efektif untuk mengolah data. Selain itu juga menyediakan berbagai fasilitas yang memudahkan pemakai dalam mencari berbagai macam informasi yang dibutuhkan. SMP Kartika XI-3 Jakarta Timur membutuhkan sekali adanya sistem informasi dalam hal pengolahan data nilai siswa. Untuk itulah penulis mencoba membuat penelitian mengenai sistem pengolahan nilai rapor pada SMP Kartika XI-3 Jakarta Timur yang sampai saat ini belum terkomputerisasi. Sistem yang ada pada SMP Kartika XI-3 Jakarta Timur ini masih dilkukan secara manual, mulai dari pencataan data nilai siswa, sampai penyimpanan data-data lainnya yang berhubungan dengan proses pengolahan hingga sampai pembuatan laporan, sehingga memungkinkan pada saat proses berlangsung terjadi kesalahan dalam pencatatan, kurang akuratnya laporan yang dibuat dan keterlambatan dalam pencarian data-data yang diperlukan. Dengan menggunakan metode pengembangan perangkat lunak waterfall web ini dapat dibuat, mulai dari komunikasi, perencanaan, perancangan, pembuatan, hingga pengembangan. Sistem informasi pengolahan nilai siswa berbasis web pada SMP Kartika XI-3 Jakarta Timur yang dibuat ini dapat digunakan sebagai sarana informasi bagi siswa dan guru mengenai pelaporan data nilai siswa dengan memanfaatkan sistem komputerisasi yang diolah dengan menggunakan bahasa pemrograman web PHP serta database MySQL.
\end{abstract}

Kata Kunci: Sistem Informasi, Pengolahan Nilai, Metode Waterfall

Abstract - Web-based information system nowadays has become an effective means for data processing. Beside providing various facilities which enable the user to search for various type of information needed. SMP Kartika XI-3 East Jakarta fully needs an information system in terms of data processing student scores. That is why the writer tries to make the research of the processing system grades the SMP Kartika XI-3 East Jakarta, which up to now has not been computerized. The existing system on SMP Kartika XI-3 East Jakarta is still done manually, from input the data value of students, to deposit other data related to the processing of up to preparing reports, one of those phases might trigger some mistakes in doing inputing, less of accurateness from the reports made by and the lateness in finding required data or documents. By using waterfall web development method this web can be made, from communication, planning, designing, making, until development. Information processing system of web-based student scores on SMP Kartika XI-3 East Jakarta who made can be used as a means of information for students and teachers about the student data reporting value by utilizing a computerized system that is processed, using a web programming language PHP and database MySQL.

Keywords: : Information system, Value Processing, Waterfall Method

\section{PENDAHULUAN}

Kemajuan teknologi informasi pada masa sekarang ini mengalami kemajuan yang sangat pesat, ditandai dengan adanya pengolahan bidang pekerjaan yang pada awalnya dikelola menggunakan cara yang manual kini telah dikelola menggunakan hasil teknologi. Baik itu berupa mesin, peralatan digital, bahkan teknologi pengolahan yang menggunakan komputer. Peranan teknologi informasi kini sangat dipelukan dalam segala aspek pekerjaan manusia. Selain memberikan kemudahan didalam mengoperasikannya juga dampak efisiensi kerja yang cepat, tepat, dan akurat. Media website merupakan salah satu produk teknologi informasi serta sistem informasi yang dikembangkan secara online atau lebih dikenal dengan internet.

Seperti halnya yang ada di SMP Kartika XI-3 Jakarta Timur dimana masih belum menggunakan komputer dalam proses pembelajaran mereka. Baik dalam proses ajar-mengajar maupun proses akademik yang lain. Salah satu diantaranya adalah sistem pengolahan nilai rapor siswa, nilai rapor siswa sampai saat ini masih dipercaya dan 
digunakan sebagai salah satu tolak ukur keberhasilan siswa menempuh pendidikan di sekolah.

Nilai rapor siswa merupakan kumpulan nilai akhir dari semua mata pelajaran yang ditempuh siswa pada satu semester tahun ajaran tertentu. Untuk menghasilkan nilai rapor, wali kelas membutuhkan data nilai dari semua guru pengampu mata pelajaran untuk di masukkan ke dalam buku nilai besar kemudian ditulis ke dalam rapor. Sehingga sering terjadi kesalahan dan keterlambatan dalam mengolah data rapor.

Siswa hanya dapat melihat nilai pada akhir semester. Setelah rapor dikembalikan lagi kepada sekolah rapor akan disimpan di dalam lemari besar. Dan setiap tahun ajaran baru data nilai rapor harus dimasukkan ke dalam buku besar yang berisikan nilai rapor dari semester ke semester berikutnya. Dan juga jika siswa meminta rapor mereka untuk keperluan tertentu, maka para staff tata usaha yang akan mencari rapor siswa yang bersangkutan di dalam lemari besar. Dengan sistem yang seperti itu memerlukan waktu yang sangat lama dan membutuhkan tenaga yang banyak. Sedangkan jumlah siswa setiap tahun ajaran baru di sekolah selalu meningkat. Oleh karena itu diperlukan suatu upaya untuk mengubah sistem pengolahan nilai rapor yang digunakan saat ini.

Dengan adanya sistem informasi pengolahan nilai siswa berbasis web ini di harapkan dapat membantu aktivitas pengolahan nilai rapor para siswa dan siswi serta juga menyajikannya ke dalam bentuk laporan data nilai yang cepat, mudah, dan akurat. Sehingga dengan adanya sistem informasi pengolahan nilai siswa yang akan dirancang ini dapat diterapkan dengan baik dan membantu dalam meminimalisasi permasalahan yang tengah dihadapi SMP Kartika XI-3 Jakarta Timur.

Sebagai bahan acuan dan perbandingan, peneliti melakukan study literature pada beberapa penelitian yang telah dilakukan sebelumnya. Diantaranya penelitian yang dilakukan oleh (Romadhoni, Widiyaningtyas, \& Pujianto, 2015) yang berjudul Implementasi Model Waterfall Pada Pengembangan Sistem Informasi Alumni SMKN 1 Jenangan Ponorogo. Kemudian penelitian yang dilakukan (Melan, 2016) Perancangan Sistem Informasi Akademik Berbasis Web Pada SMK Pasar Minggu Jakarta. Berikutnya penelitian yang dilakukan oleh (Yulianto \& Atmaja, 2018) yang berjudul Rancang Bangun Sistem Informasi Kurikulum 2013 Tingkat Sekolah Dasar Berbasis Web dengan SDLC Waterfall. Selanjutnya penelitian yang dilakukan oleh (Pratama, Wicaksono, \& Saputra, 2018) yang berjudul Pengembangan Sistem Informasi Manajemen Perpustakaan Pada Ruang Baca Fakultas Ilmu Komputer Universitas Brawijaya. Terakhir penelitian yang dilakukan oleh (Mariana \& Amrin, 2019) yang berjudul Implementasi Model Waterfall
Untuk Pengembangan Sistem Informasi Surat Berjalan PKK DKI Jakarta.

\section{METODOLOGI PENELITIAN}

Metode yang digunakan pada pengembangan perangkat lunak ini menggunakan model waterfall menurut (Pressman, 2010) mengemukakan "model waterfall atau biasa disebut klasik Life Cycle adalah model klasik yang bersifat sistematis, berurutan

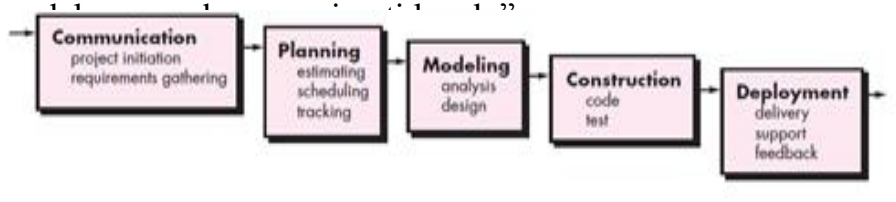

Sumber : Pressman (2010)

Gambar 1. Model Pengembangan Waterfall

Aktivitas-aktivitas dalam waterfall model adalah sebagi berikut :

\section{Communication}

Langkah ini merupakan analisis terhadap kebutuhan software, dan tahap untuk mengadakan pengumpulan data dengan melakukan pertemuan dengan customer, maupun mengumpulkan data-data tambahan baik yang ada di jurnal, artikel, maupun dari internet.

\section{Planning}

Proses planning merupakan lanjutan dari proses communication (analysis requirement). Tahapan ini akan menghasilkan dokumen user requirement atau bisa dikatakan sebagai data yang berhubungan dengan keinginan user dalam pembuatan software, termasuk rencana yang akan dilakukan.

\section{Modeling}

Proses modeling ini akan menerjemahkan syarat kebutuhan ke sebuah perancangan software yang dapat diperkirakan sebelum dibuat coding. Proses ini berfokus pada rancangan struktur data, arsitektur software, representasi interface, dan detail (algoritma) prosedural. Tahapan ini akan menghasilkan dokumen yang disebut software requirement.

\section{Construction}

Construction merupakan proses membuat kode. Coding atau pengkodean merupakan penerjemahan desain dalam bahasa yang bisa dikenali oleh komputer. Programmer akan menerjemahkan transaksi yang diminta oleh user. Tahapan inilah yang merrupakan tahapan secara nyata dalam mengerjakan suatu software, artinya penggunaan komputer akan dimaksimalkan dalam tahapan ini. Setelah pengkodean selesai akan dilakukan testing terhadap sistem yang telah dibuat tadi. Tujuan testing adalah menemukan kesalahan-kesalahan terhadap sistem tersebut untuk kemudian bisa diperbaiki.

\section{Deployment}

Tahapan ini bisa dikatakan final dalam pembuatan sebuah software atau sistem. Setelah melakukan 
analisis, desain dan pengkodean maka sistem yang sudah jadi akan digunakan oleh user. Kemudian software yang telah dibuat harus dilakukan pemeliharaan secara berkala.

\section{HASIL DAN PEMBAHASAN}

\section{Analisa Kebutuhan}

Analisis kebutuhan yang diusulkan dibagi menjadi dua (2) kebutuhan, yaitu kebutuhan pengguna dan kebutuhan sistem.

\section{A. Kebutuhan Pengguna}

A.1.Skenario Kebutuhan Admin :

a) Mengelola data mata pelajaran

b) Mengelola data pribadi peserta didik.

c) Mengelola data pribadi pendidik (wali kelas dan pendidik bidang studi).

d) Mengelola data kelas.

e) Mengelola data rapor peserta didik.

f) Mengelola laporan pengolahan nilai peserta didik.

A.2. Skenario Kebutuhan Wali Kelas :

a) Melihat data pribadi.

b) Melihat data peserta didik.

c) Input nilai peserta didik ke dalam website.

d) Mencetak rapor peserta didik.

A.3. Skenario Kebutuhan Orang Tua / Wali Peserta Didik :

a) Melihat data pribadi peserta didik.

b) Melihat rapor peserta didik.

c) Mencetak rapor peserta didik.

B. Kebutuhan Sistem

B.1. Kebutuhan Sistem untuk Admin :

a) Admin harus melakukan login untuk mengakses website dengan memasukkan username (nomor induk pegawai yayasan / NIPY) dan password yang telah tervalidasi.

b) Admin dapat mengakses data yang berkaitan dengan proses pengolahan nilai rapor peserta didik, diantaranya adalah pengolahan data pengguna, pengolahan mata pelajaran, pengolahan rapor peserta didik, pembuatan laporan pengolahan nilai rapor peserta didik, dan pencetakan laporan pengolahan nilai rapor peserta didik.

c) Admin melakukan logout setelah selesai mengakses website.

B.2. Kebutuhan Sistem untuk Wali Kelas :

a) Wali kelas harus melakukan login untuk mengakses website dengan memasukkan username (nomor induk pegawai yayasan) dan password yang telah tervalidasi.

b) Wali kelas dapat mengakses sistem, diantaranya adalah melihat data pribadi dan data peserta didik, input nilai rapor peserta didik, dan mencetak rapor peserta didik. c) Wali kelas melakukan logout setelah selesai mengakses website.

B.3. Kebutuhan Sistem untu Orang Tua / Wali Peserta Didik :

a) Orang tua / wali peserta didik harus melakukan login untuk mengakses website dengan memasukkan username (nomor induk peserta didik) dan password yang telah tervalidasi.

b) Orang tua / wali peserta didik dapat mengakses sistem, diantaranya adalah melihat data pribadi dan rapor peserta didik dan mencetak rapor peserta didik.

c) Orang tua / wali peserta didik melakukan logout setelah selesai mengakses website.

\section{Desain}

Dalam penelitian desain system informasi perpustakaan ini menggunakan diagram Unified Modeling Language (UML) yang diuraikan kedalam tahapan sebagai berikut :

A. Desain Sistem

1. Use Case Diagram Admin

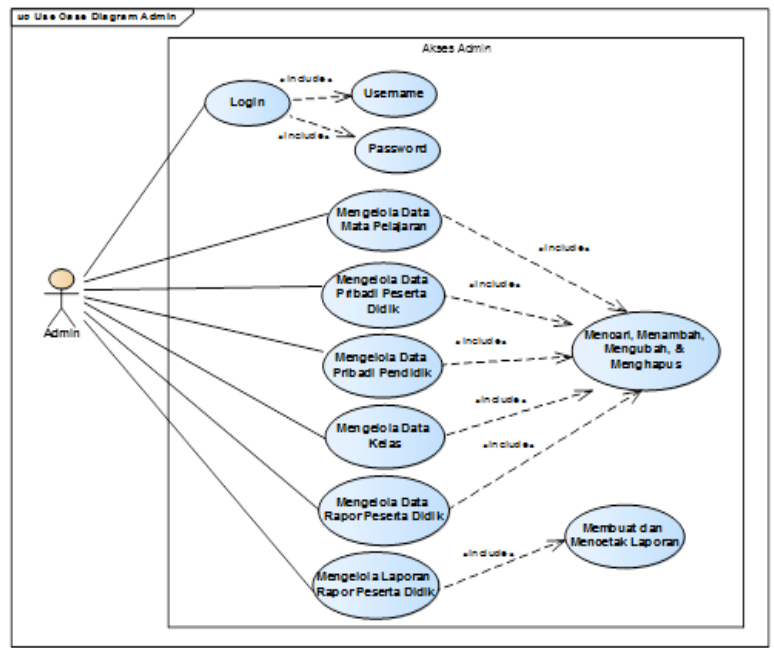

Gambar 2. Use Case Diagram Admin

2. Use Case Diagram Wali Kelas

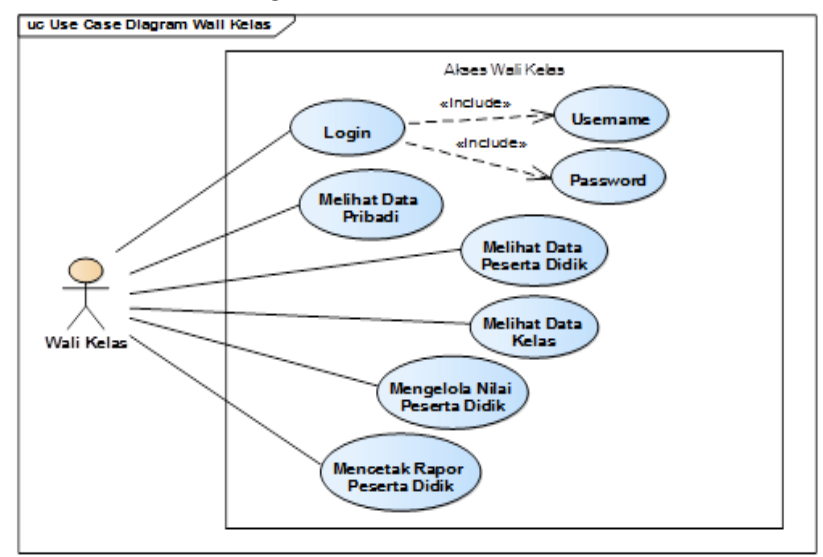

Gambar 3. Use Case Diagram Wali Kelas 
3. Use Case Diagram Orang Tua / Wali

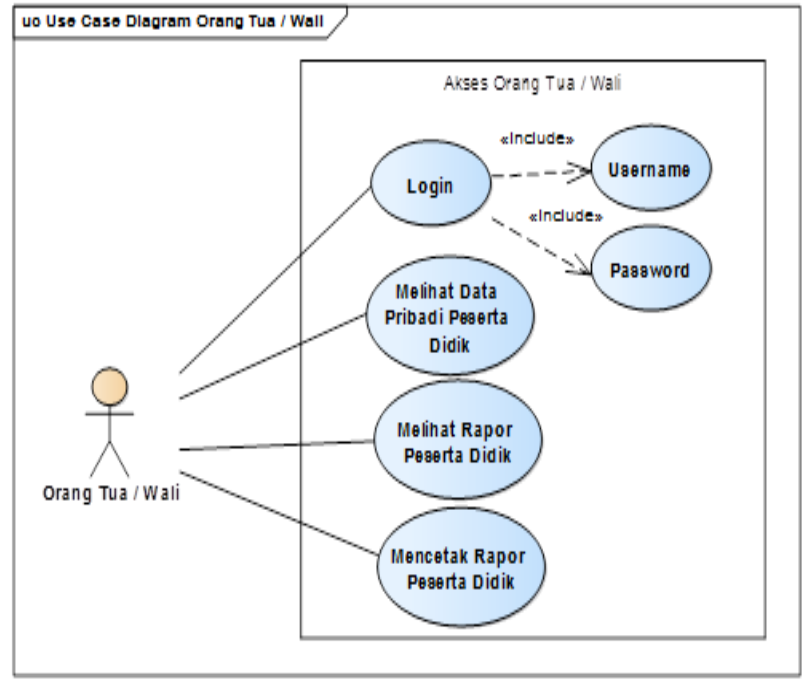

Gambar 4. Use Case Diagram Orang Tua / Wali

\section{Classs Diagram}

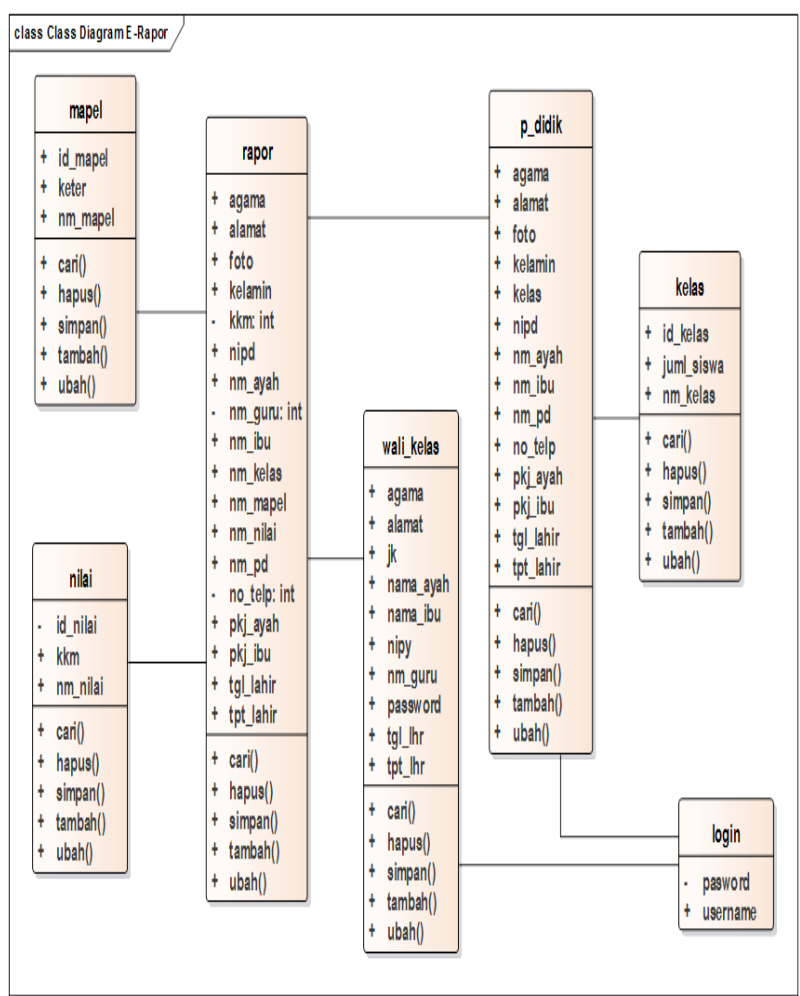

Gambar 5. Class Diagram

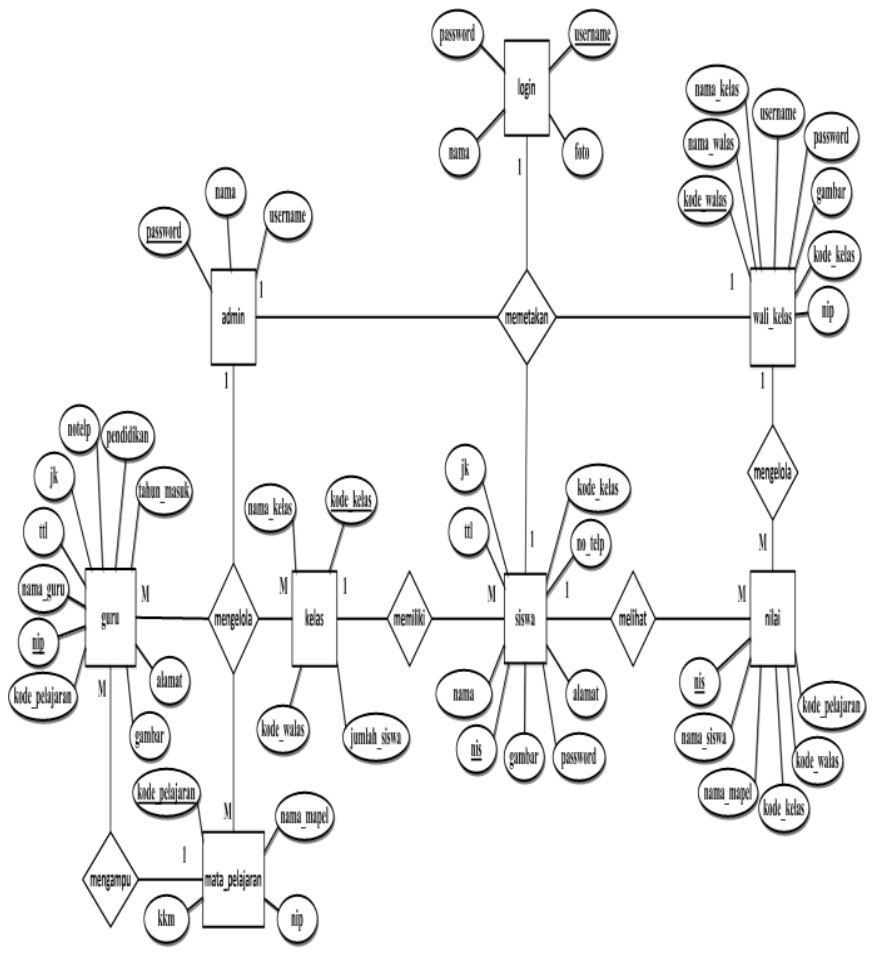

Gambar 6. Entity Relationship Diagram

2. 2. Logical Record Structure

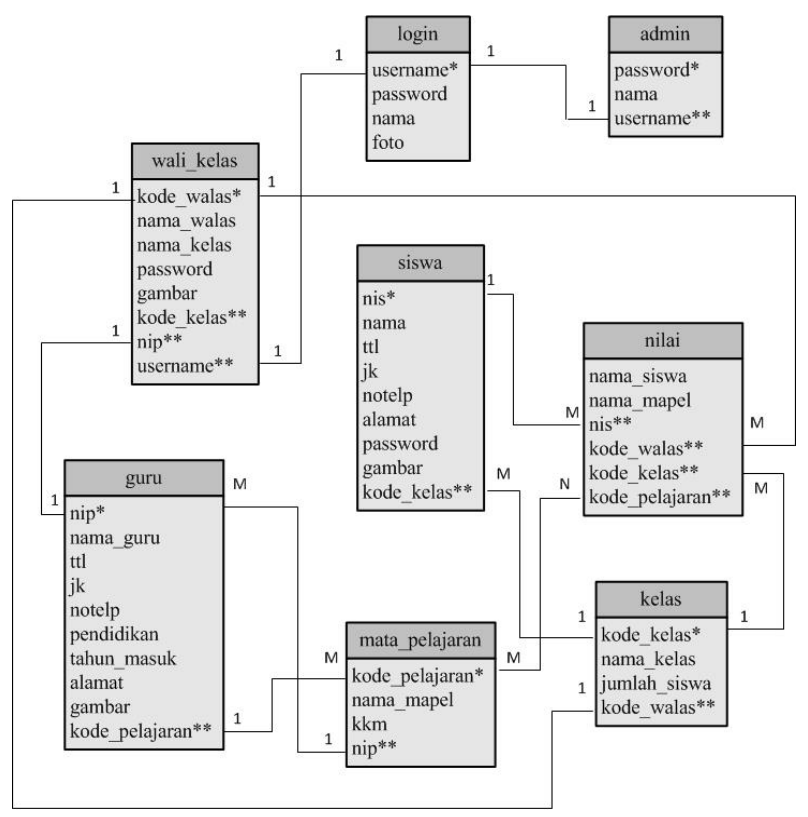

Gambar 7. Logical Relational Structure 


\section{Implementasi Rancangan Antar Muka}

Implementasi rancangan antar muka pada sistem informasi pengolahan nilai berdasarkan hasil rancangan antar muka.

1. Halaman Index Admin

Setelah melakukan Login, administrator bisa menggunakan menu master data yang terdiri dari data siswa, data guru, data wali kelas, data kelas, data mata pelajaran. Lalu Pengolahan nilai yang terdiri data data nilai ganjil dan data nilai genap. Serta menu laporan.

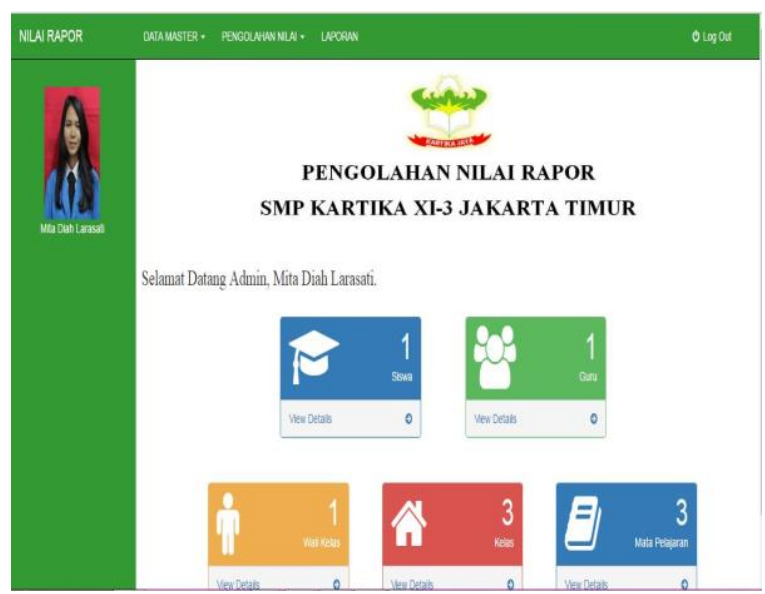

Gambar 8. Halaman Index Admin

2. Halaman Data Siswa

Pada halaman data siswa administrator bisa mengelola data seperti meng-input, meng-edit, dan hapus data.

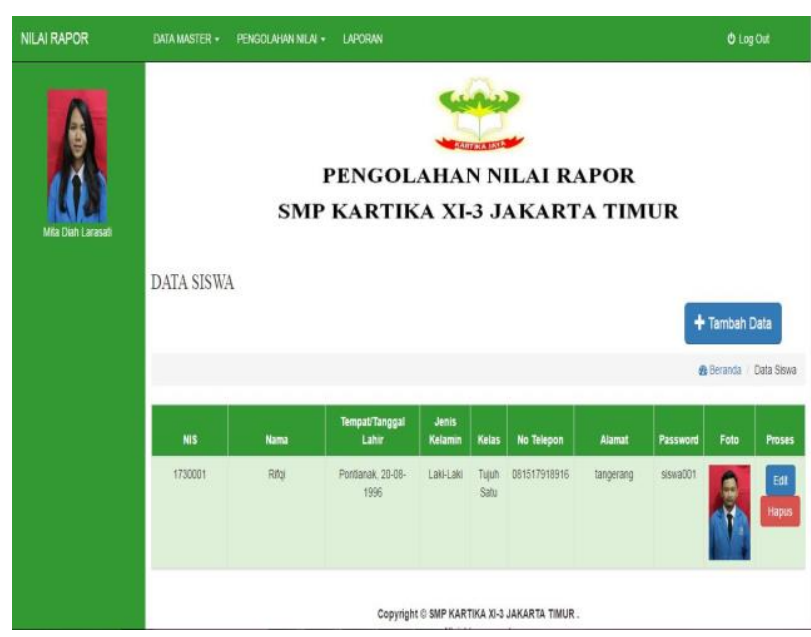

Gambar 9. Halaman Data Siswa

3. Halaman Nilai Ganjil

Pada halaman Nilai Ganjil administrator bisa melihat data yang tersedia di halaman tersebut.

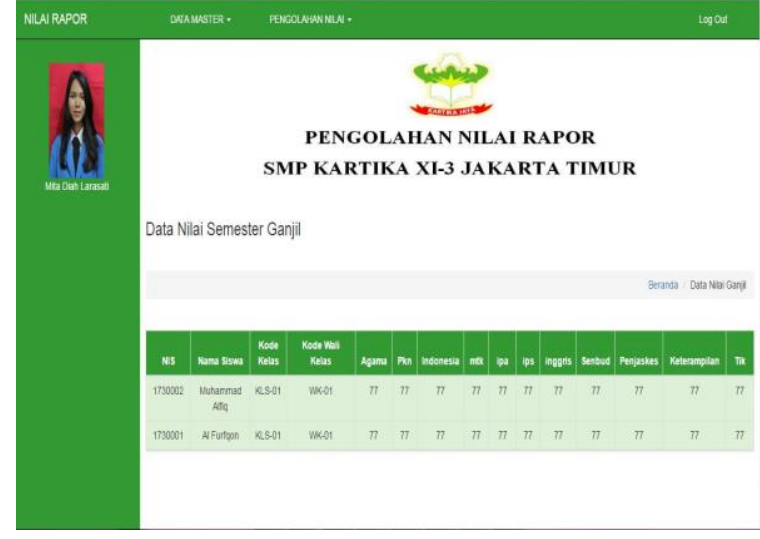

Gambar 10. Halaman Nilai Ganjil

4. Halaman Index Wali Kelas

Setelah melakukan Login, Wali kelas bisa menggunakan menu master data yang terdiri dari data siswa, data guru, data wali kelas, data kelas, data mata pelajaran. Lalu Pengolahan nilai yang terdiri data data nilai ganjil dan data nilai genap.

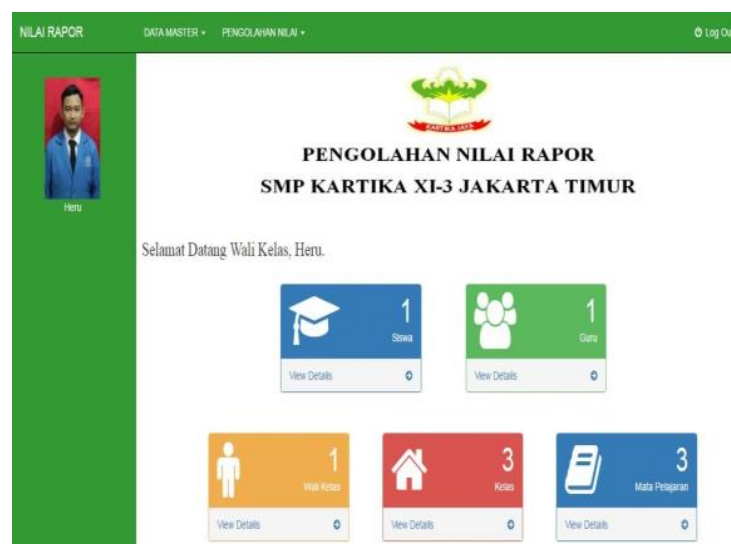

Gambar 11. Halaman Index Wali Kelas

5. Halaman Data Siswa

Pada Halaman data siswa Wali kelas bisa melihat data siswa serta memasukkan data nilai siswa.

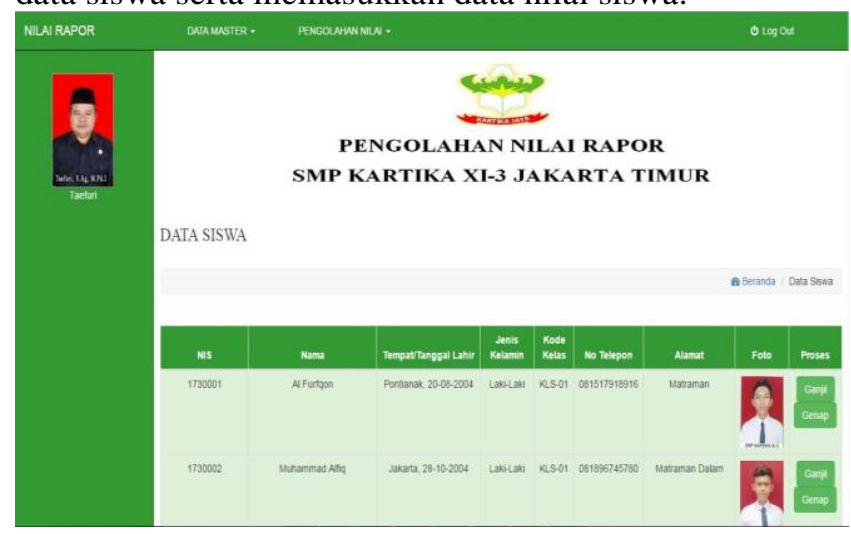

Gambar 12. Halaman Data Siswa 
6. Halaman Profil Sekolah

Pada halaman profil sekolah siswa bisa melihat profil, visi, serta misi dari sekolah SMP Kartika XI-3 Jakarta Timur.

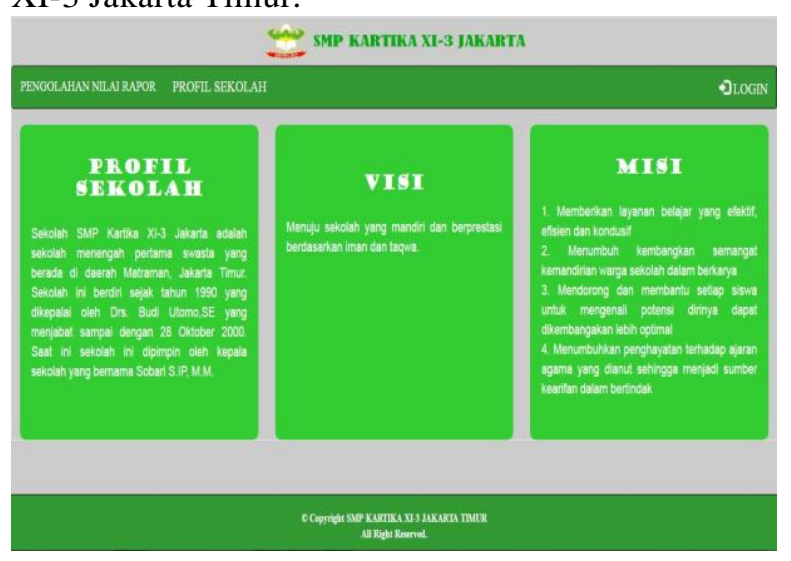

Gambar 13. Halaman Profil Sekolah

7. Halaman Login Siswa

Siswa harus melakukan login terlebih dahulu untuk dapat menggunakan modul-modul yang tersedia jika login berhasil, maka menu-menu yang sesuai dengan kategori user tersebut akan ditampilkan.

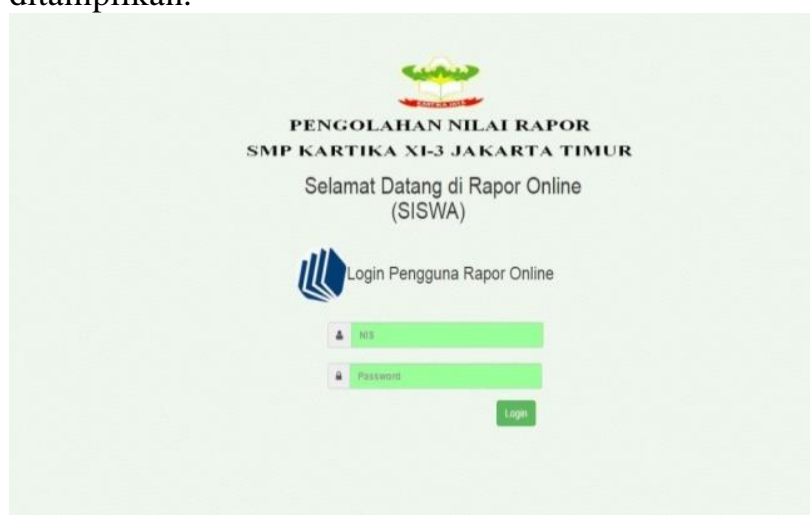

Gambar 14. Halaman Login Siswa

\section{KESIMPULAN}

Dari penulisan tugas akhir tentang perancangan sistem informasi pengolahan nilai berbasis web pada SMP Kartika XI-3 Jakarta Timur, maka penulis dapat menarik kesimpulan sebagai berikut:

1. Dengan sistem informasi pengolahan nilai berbasis web pada SMP Kartika XI-3 Jakarta Timur yang sudah terkomputerisasi ini dapat membantu mengurangi kesalahan yang terjadi pada sistem yang masih di gunakan oleh SMP Kartika XI-3 Jakarta Timur.

2. Dapat meningkatkan kinerja pegawai terutama dalam pengolahan data guru, data siswa, data kelas, data wali kelas, data mata pelajaran, dan pengolahan nilai siswa yang selama ini masih kurang efisien.

3. Tingkat keamanan data lebih terjaga karena disimpan ke dalam suatu database yang terkomputerisasi.

4. Perancangan sistem informasi pengolahan nilai berbasis web pada SMP Kartika XI-3 Jakarta Timur ini dapat mempermudah dalam hal pembuatan laporan serta mempermudah dalam hal pencarian data.

\section{REFERENSI}

Mariana, A. N., \& Amrin, A. (2019). Implementasi Model Waterfall Untuk Pengembangan Sistem Informasi Surat Berjalan PKK DKI Jakarta. Jurnal Riset Komputer (Jurikom), 6(5), 453 459. Retrieved from https://www.ejurnal.stmik-

budidarma.ac.id/index.php/jurikom/article/vie w/1392

Melan, S. (2016). Perancangan Sistem Informasi Akademik Berbasis Web Pada SMK Pasar Minggu Jakarta. Jurnal Informatika, 3(1), 9199.

Pratama, I. G. Y., Wicaksono, S. A., \& Saputra, M. C. (2018). Pengembangan Sistem Informasi Manajemen Perpustakaan Pada Ruang Baca Fakultas Ilmu Komputer Universitas Brawijaya. Jurnal Pengembangan Teknologi Informasi Dan Ilmu Komputer Universitas Brawijaya, 2(12), 6669-6678.

Pressman, R. S. (2010). Pendekatan Praktisi Rekayasa Perangkat Lunak Edisi 7. Yogyakarta: Andi Offset.

Romadhoni, E. N. A., Widiyaningtyas, T., \& Pujianto, U. (2015). Implementasi Model Waterfall Pada Pengembangan Sistem Informasi Alumni SMKN 1 Jenangan Ponorogo. Seminar Nasional Sistem Informasi Indonesia (SESINDO) Departemen Sistem Informasi, Institut Teknologi Sepuluh Nopember, (2-3 November 2015), 445-452. Retrieved from http://is.its.ac.id/pubs/oajis/index.php/home/de tail/1594/Implementasi-Model-WaterfallPada-Pengembangan-Sistem-InformasiAlumni-SMKN-1-Jenangan-Ponorogo

Yulianto, S. V., \& Atmaja, A. P. (2018). Rancang Bangun Sistem Informasi Kurikulum 2013 Tingkat Sekolah Dasar Berbasis Web dengan SDLC Waterfall. Jurnal Sisfo ITS, 07(02), 149-164. 